Skepticism and Cognitivism 



\section{Skepticism and Cognitivism}

A Study in the Foundations of Knowledge

Oliver A. Johnson

UNIVERSITY OF CALIFORNIA PRESS

Berkeley Los Angeles London 
University of California Press

Berkeley and Los Angeles, California

University of California Press, Ltd.

London, England

Copyright $(\odot 1978$ by The Regents of the University of California ISBN 0-520-03620-4

Library of Congress Catalog Card Number 77-91743

Printed in the United States of America 


\section{To Carol,}

with love and appreciation 
